Portland State University

PDXScholar

8-4-1982

\title{
The Effect of Causal Attribution and Self-Evaluation on Mood
}

William N. Werner

Portland State University

Follow this and additional works at: https://pdxscholar.library.pdx.edu/open_access_etds

Part of the Cognition and Perception Commons

Let us know how access to this document benefits you.

Recommended Citation

Werner, William N., "The Effect of Causal Attribution and Self-Evaluation on Mood" (1982). Dissertations and Theses. Paper 3211.

https://doi.org/10.15760/etd.3202

This Thesis is brought to you for free and open access. It has been accepted for inclusion in Dissertations and Theses by an authorized administrator of PDXScholar. Please contact us if we can make this document more accessible: pdxscholar@pdx.edu. 
AN ABSTRACT OF THE THESIS OF William N. Werner for the Master of Science in Psychology presented August 4, 1982.

Title: The Effects of Causal Attributions and Selfevaluations on Mood.

APPROVED BY MENBERS OF THE THESIS COMMITTEE:

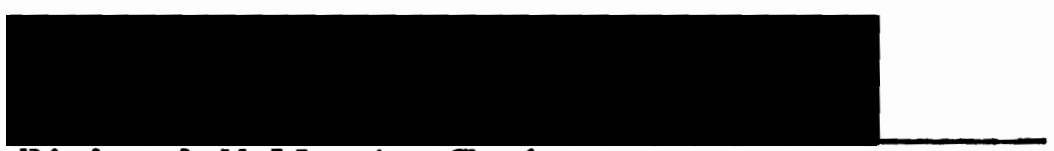

Richard Wollert, Chairman

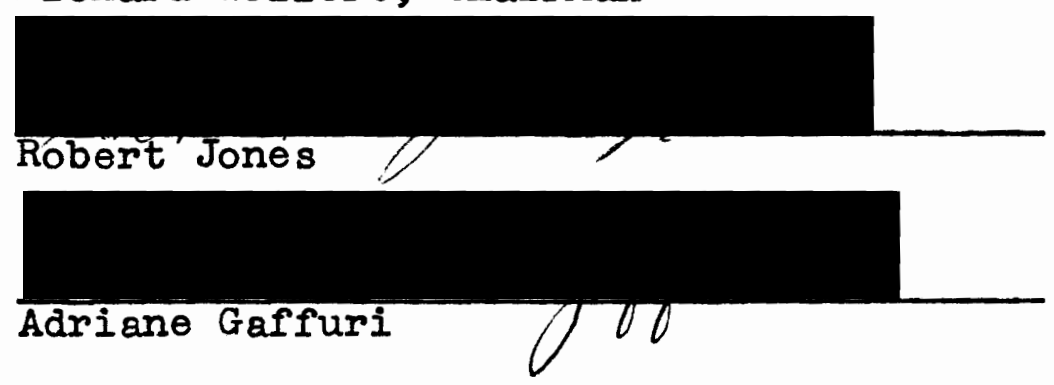

The present study was designed to test the causal locus hypothesis, and to develop and explore the selfevaluational hypothesis. The causal locus hypothesis is based on attribution, which is a person's perception of cause. The hypothesis holds that persons making internal attributions (self-caused) for failure and external attributions (not self-caused) for success experience more negative postoutcome mood than persons making external attributions for failure and internal attributions for success. The hypothesis was derived from major theories of attribution, but was not experimentally tested until 
recently (Wollert et al., 1981).

Subjects were assigned to one of three attributioninduction groups, internal, external, and neutral (no induction). Task descriptions were used to prepare subjects to "predict" (internal induction) or "guess" (external induction) the correct response. Subjects in the neutral attribution group were simply told to "choose". Subjects then completed a word association task in which they were instructed to check one of two words more commonly associated with a given stimulus word. In actuality, all associate-word pairs were chosen so that either word would be chosen with equal likelihood. Half of the subjects in each condition were given success feedback ( $80 \%$ correct) and half were given failure feedback ( $20 \%$ correct). Mood was assessed after the task. The results paralelled those of Wollert et al. (1981). Outcome (success or failure) affected mood, but attribution did not. The causal locus hypothesis was not supported. The self-evaluational hypothesis holds that evaluation about oneself in relation to events affects mood, and may do so independently of attributional content. For example, if an employee perceives she caused herself to fail in gaining promotion, she has made an attribution. If she blames herself for that event, she has made a selfovaluation related to the event. It was hypothesized that 
the self-evaluations implie $\$$ by attributions, and not the attributions themselves, affect mood. Self-evaluational data collected during the experiment supported this hypothesis. When self-evaluations (credit or blame) were related to attributions, mood was affected as predicted by the causal locus hypothesis. When self-evaluations were independent of attributions, mood was related to self-evaluation and not to attribution. 
THE EFFECT OF CAUSAL ATTRIBUTION AND SELFEVALUATION ON MOOD

by

WILIIAM N. WERNER

A thesis submitted in partial fulfillment of the requirements for the degree of

MASTER OF SCIENCE

in

PSYCHOLOGY

Portlend State University

1982 
TO THE OFFICE OF GRADUATE STUDIES AND RESEARCH:

The members of the Committee approve the thesis

of William N. Werner presented August 4, 1982.
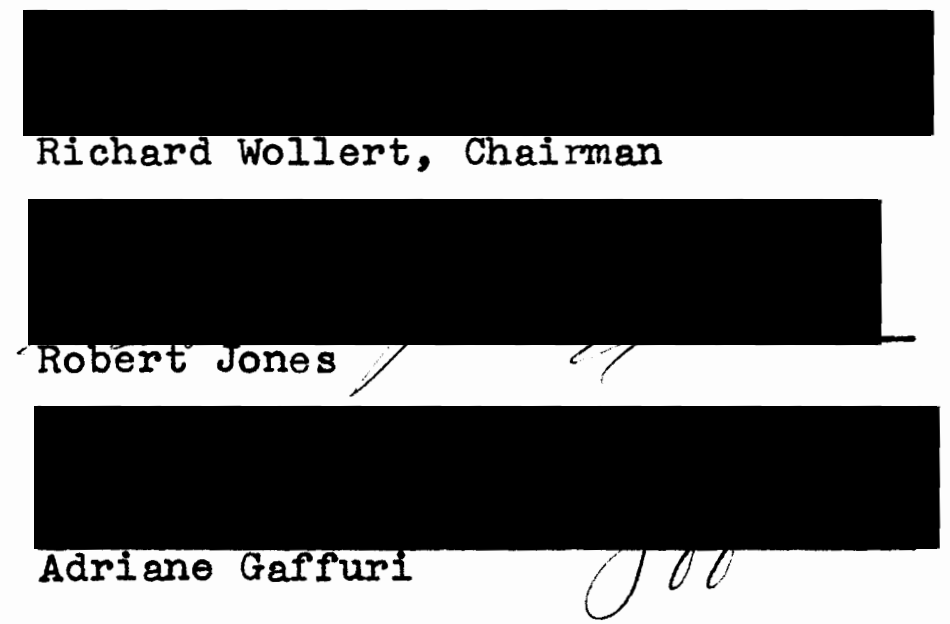

APPROVED:

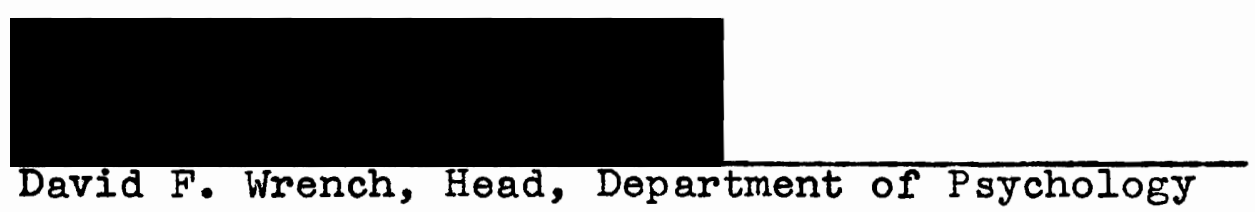

Stanley E. Rauch, Dean of Graduate Studies and Research 


\section{ACKNOWIEDGMENTS}

My sincere thanks go to Richard Wollert whose research and theoretical conceptualizations made this study possible.

I also wish to thank Bob Jones for patiently instructing this novice in the ways of the computer.

Further thanks go to Adriane Gaffuri for her constructive comments and helpful support.

Finally. I wish to thank Richard Schulz for reviewing the paper and suggesting worthy additions. 
TABLE OF CONTENTS

PAGE

ACKNOWLEDGMENTS

iii

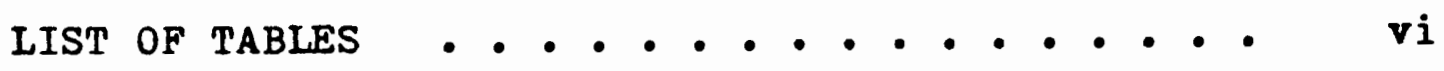

CHAPTER

I INTRODUCTION AND LITERATURE REVIEW • . 1

II METHOD . . . . . . . . . 17

Subjects . . . . . . . . 17

Tasks and Materials ...... 17

Procedure ......... . 20

III RESULTS . . . . . . . . . . 22

Manipulation Check . . . . . 22

Analysis of Mood .. . . . . 24

Correlational Analysis of the

Relationship between Mood.

Attribution, and Self-

evaluation ........

IV DISCUSSION . . . . . . . . 32

Causal Locus Hypothesis . . . 32

Self-evaluational Hypothesis . . 34

REFERENCE LIST • • • • • • • • • • 37

APPENDIX A

APPENDIX B ............... . . . 54

APPENDIX C C............... 57

APPENDIX D D . . . . . . . . . 58 
PAGE

APPENDIX E

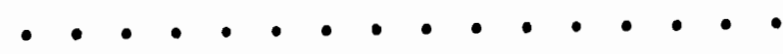
58 APPENDIX F

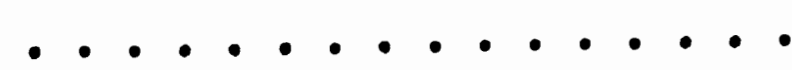
61 APPENDIX G

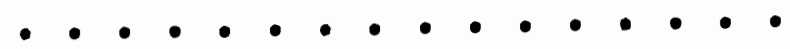
63 


\section{IIST OF TABLES}

TABLE

PAGE

I Means and Standard Deviations for Mood,

Control, and Credit or Blame Checklists • . 23

II Correlations between Mood Checklists

within Conditions . . . . . . . . 25

III Correlations between Mood Checklists and

Control Checklists . . . . . . . 27

IV Correlations between Mood Checklists and

Credit or Blame Checklists . . . . . 28

V Correlations between Control and Credit

or Blame . . . . . . . . . . . 30

VI Partial Correlations between Depression and Credit or Blame, Controlling for Control • 31

VII Partial Correlations between Depression and

Control, Controlling for Credit or Blame - 31 


\section{CHAPTER I}

\section{INTRODUCTION AND LITERATURE REVIEW}

When a person perceives the cause of an event or outcome, she is said to attribute the outcome to that cause; that is she makes an attribution about the outcome. For instance, if an employee fails to gain promotion, she might make the attribution that her supervisor dislikes her. Or she may attribute the failure to her own lack of ability. It is important to realize that to most theorists attribution is only the perception of cause of an outcome, and not any self-evaluations which may accompany that perception. If this employee perceives the cause of her failure as inability, and then blames herself, the first process is an attribution, and the second, a self-evaluation.

A great deal of research has been devoted to the process of attribution and its effects. In the past decade a sizeable portion of attribution theory has focused on the effect of attribution on mood. Theorists have asked "How do the perceived causes of success or failure affect a person's mood?" The question may be rephrased "What role do causal attributions play in the development of depression?" Several models have been proposed. Prominent among these is the attributional theory presented by weiner, Frieze, Kukla, Reed, Rest, and Rosenbaum. (1971). 
This model postulates that individuals attribute the outcome of an achievement-related event to four causal elements: ability, effort, task difficulty, and luck. These components can be divided along to' dimensions: locus of control (internal vs. external) and stability (enduring vs. situational). Within the locus of control dimension, ability and effort are considered internal. That is, they describe qualities of the person undertaking the task. In contrast, task difficulty and luck are environmental factors, externally determined and beyond the person's control. Further, task difficulty and ability are relatively enduring characteristics on the stability dimension, whereas effort and luck are more situational and hence unstable. According to the model, a person's affective state following an outcome depends on the types of attributions (stable) unstable, internal/external) the person makes about that outcome. For instance, Weiner et al. (1971) maintained that internal attributions for success or failure produce more positive or more negative affects, respectively, than external attributions. From this prediction it follows that people who make internal attributions for failure (e.g. insufficient ability) and external attributions for success (e.g. luck) experience more negative affect than those who make internal attributions for success or external attributions for failure. This has 
been called the causal locus hypothesis (Wollert, Heinrich, \& Wood, 1981).

Seligman's reformulated learned helplessness model of depression (Abramson, Seligman, \& Teasdale, 1978) incorporated three attributional dimensions: internal/ external, stable/unstable, and global/specific. According to this theory people become helpless and vulnerable to depression when they perceive that their outcomes are unrelated to their responding. The specific attributions they make about this helplessness will determine the form that depression might take. For example, Abramson et al. (1978) (p. 69) have proposed "Those people who typically tend to attribute failure to global, stable, and internal factors should be most prone to general and chronic helplessness with low self-esteem". A common thread, then, of these two major attributional models is the causal locus hypothesis, the internal/external attributional dimension of depression.

In sumary, two major theories hold that attributions are related to mood disorders, and the causal locus hypothesis is a primary component of both models. This hypothesis has been tested in several ways. The most common method is to select depressed and nondepressed subjects, present success or failure, and assess and compare the attributions these subjects make about the outcomes. 
If the causal locus hypothesis is valid, depressed subjects should be more likely than nondepressed subjects to make internal attributions for failure and external attributions for success. The following briefly summarizes some of the studies using this approach.

The work of Klein, Fencil-Morse, and Seligman (1976) typifies this method. In this study 81 undergraduate college students were given the Beck Depression Inventory (BDI) and divided into depressed and nondepressed groups depending on their scores. Some subjects in each group worked solvable problems on which they consistently succeeded while others worked unsolvable problems on which they consistently failed. All subjects completed a postexperiment questionnaire which assessed their attributions. The results supported the causel locus hypothesis. Depressed subjects in the unsolvable group had higher internality scores than nondepressed subjects. In contrast, in the solvable condition, nondepressed subjects had somewhat higher internality scores than depressed subjects. The authors concluded that "depressed subjects were more likely than nondepressed subjects to attribute their performance to their abilities rather than to task difficulty when they failed, but not when they succeeded." (p. 513). Work by Kuiper (1978) provides some further support. Subjects were assigned to depressed or nondepressed groups 
based on extreme scores on the Costello-Comrey Depression Scale, and given a Word Association Test (WAT). On this task subjects were asked to choose one of two words most commonly associated with a given word. In actuality both choices had equal probability of selection. Half of the subjects in each group were told they had failed on $80 \%$ of their responses. Half were told they had succeeded on $80 \%$ of their responses. Attributions were assessed after the task. For failure outcomes, depressives generally made internal causal attributions, while nondepressives made external attributions.

Rizley (1978) (Experiment 1) conducted a similar study, assigning college students to depressed or nondepressed groups depending on their scores on the Beck Depression Inventory. Subjects were asked to predict a number following a series of numbers. Outcomes were controlled by chance. Following their responses some subjects in each group were informed they had failed while others were informed they had passed. Causal attributions were assessed after the task. Subjects in the depressed group "rated internal causal factors (effort and ability) to be more important determinants of failure but less important determinants of success than did nondepressed subjects." (p. 32).

Seligman, Abramson, and Semmel (1979) developed an 
attributional style scale and administered it to a group of college students. The scale consisted of 12 hypothetical situations, half describing good outcomes, half describing bad outcomes. Subjects were instructed to imagine themselves in each situation and describe the the cause of that outcome. They were then given the Beck Depression Inventory and assigned to depressed or nondepressed groups based on these scores. As predicted by the causal locus hypothesis, subjects in the depressed group, compared to those in the nondepressed group, attributed bad outcomes to internal causes and good outcomes to external causes. In a related study, Harvey (1981) administered the Beck Depression Inventory to undergraduate college women and selected depressed and nondepressed subjects on the basis of high and low scores. Rather than present positive or negative events as Rizley (1978) had done, Harvey instructed his subjects to list their own positive and negative events. As in the earlier study, Harvey's subjects then described the cause of each event. Independent trained coders, unaware of the study's purpose, rated these causes on an internal/external scale. It was found that the depressed subjects attributed negative events more to internal causes than did the nondepressed. The findings of these two studies are consistent with each other and with the causal locus hypothesis. 
In summary, these five studies provide support for the causal locus hypothesis.

A second method of testing the causal locus hypothesis is to select subjects with internal or external attributional styles, present success or failure, and assess and compare their moods after these outcomes. If the causal locus hypothesis is valid, studies using this methodology should find that internals are more likely than externals to experience negative mood for failure and positive mood for success.

Work by Pittman and Pittman (1979) suggests a person's attributional style helps determine what effect learned helplessness will have on his or her mood. In this study subjects were divided by extreme scores on the Rotter (1966) Internal-External (IE) scale into internal and external attribution groups. Half of the subjects in each group were subjected to unsolvable problems with failure feedback (high helplessness); half worked solvable problems with accurate feedback. Experimenters gave the Multiple Affect Adjective Checklist (MAACL, Zuckerman, 1960) after the task to assess mood. Among subjects in the failure groups, internals scored higher than externals in depression. This result partially supports the causal locus hypothesis.

In contrast, work by Wener and Rehm (1975) provided no support for the hypothesis. Ninety-six normal female subjects were separated into groups on the basis of median 
splits on on the Rotter IE and MMPI-D scales and given a pseudosocial intelligence task. Subjects in each of these four groups received either success or failure feedback. The MAACL was administered after the task to assess mood. No interaction was found between locus of control and outcome on the posttest mood assessment.

In a related study, Rehm (1978) assessed the effects of internal and external causes of real-life outcomes (rather than experimental outcomes) on mood. Fourteen undergraduate college students kept records of their personal lives for two weeks. Each subject recorded all pleasant and unpleasant events and the perceived cause of each event. Additionally, each subject rated his or her mood daily. Whereas positive or negative events correlated with mood, "there was no evidence that tendency to perceive contingency between events influenced mood in this study." (p. 858). Studies using this second type of methodology provide mixed support for the causal locus hypothesis. Further, this method of testing the hypothesis shares a flaw with the first method. In both methods the subject population is initially selected on the basis of one dimension: mood in the first method and attributional style in the second. In either approach it is not possible to determine the direction of the causal relationship between the dependent and independent variables. Does attributional style affect mood, as the causal locus hypothesis holds, or does mood 
affect attributional style? Recognizing the weakness in either approach, Golin, Sweeney, and Shaeffer (1981) ran a time-lag study to determine which factor, attribution or mood preceded the other. One hundred-eighty college students were given the Attributional Style questionnaire and the Beck Depression Inventory on two occasions one month apart. Crossed-lagged correlations of the data were used to determine temporal precedence. It was found that internal attributions for bad outcomes preceded depression about as often as it followed; these crossed-lagged correlations were not significantly different. This study thus provided no support for the causal locus hypothesis.

The third approach to testing the hypothesis is experimental manipulation of outcomes and causal attributions with normal subjects to directly assess the effect of these variables and their interaction on mood. Since the sequence of the variables can be precisely controlled, this approach should be the best in demonstrating cause and effect. Only two studies to date have used this methodology to test the hypothesis. A brief description of them follows.

In an experiment conducted by Wortman, Panciera, Shusterman, and Hibscher (1976) 42 female undergraduates were given a problem-solving task. All were told successful performance would reduce the number of aversive noise bursts they would receive. In actuality, all subjects received the same number of noise bursts. Success or failure outcomes were 
manipulated. "Failure" subjects were told how their performance compared with that of others, leading them to attribute their performance either to their own lack of ability or to external factors (task difficulty). Mood of all subjects was then assessed. Subjects who attributed their failure to incompetence felt considerably more stress than did subjects who made external attributions. These later reported no more stress than "successful" subjects. Although this study lends partial experimental support to the causal locus hypothesis, it did not manipulate attributions for successful outcomes.

In 1981, Wollert, Heinrich, and Wood conducted a more complete, three-part experimental test of the causal locus hypothesis. In Experiment 1 subjects were randomly assigned to tasks for which they would naturally make internal or external attributions. On the internal task subjects were asked to count the number of lights briefly flashed on a ponel. The external task required subjects to guess repeatedly whether an $\mathrm{X}$ or 0 would appear on a screen. Data were collected for each subject individually. Half of the subjects in each condition were given success feedback, and half, failure feedback. The MAACL was administered after tasks to assess mood. Subjects also rated the the internality of their attributions. As predicted subjects who failed felt more depressed about their performance. Further, subjects did make the intended attributions, but no interaction was 
found between attribution and outcome on the mood assessment. For Experiment 2, subjects were assigned to one of three attribution conditions, internal, external, and noutral, and to one of two outcome conditions, success or failure. The experiment was administered in a group setting. Pretask instructions were used to induce either internal (skill) or external (luck) attributions. The neutral group was given no attribution-inducing information. Subjects performed a Word Association Task similar to that used by Wener and Rehm (1975) and by Kuiper (1978). Half of each group received success feedback, and the other half, failure. The instruments used in Experiment 1 to assess attribution and mood were likewise used in Experiment 2. The results were comparable to those of Experiment 1. Outcome strongly affected mood, but attributions did not. Further, there was no interaction between attribution and outcome.

The methodology of Experiment 2 was used in Experiment 3, except that Experiment 3 was administered individually, and attributions were measured before as well as after performance on the Word Association Task. The results paralleled those of Experiment 2. Outcome affected mood, attribution did not, and there were no interactions between attribution and outcome.

Overall, these experiments did not confirm a promising hypothesis. The question is asked "Why has the causal locus hypothesis not been supported experimentally?" There are 
several possible explanations.

Perhaps the statistical tests used by Wollert et al. (1981) were not sufficiently sensitive to find the hypothesized effect. If the hypothesis were valid, combined mood scores for subjects in the internal/success and extermal/failure conditions would have been more positive than combined mood scores for subjects in the internal/failure and external/ success conditions. Wollert et al. (1981) used a planned comparison method to evaluate their data, comparing the sum of the means on the mood scales of the first and second group with those of the third and fourth.

Several comments may be made about this test. First, it is the most appropriate statistical test, related directly to the hypothesis. Further, combining means added power by increasing the n's and degrees of freedom. Finally, the fact that these comparisons were planned, not post hoc, added to their power. Comparing planned comparisons with post hoc comparisons, Hays (1973) (p. 610) writes:

An important point in favor of planned comparisons is this: consider any true comparisons $\boldsymbol{Y}$ among $J$ means $(J>2)$, such that $\boldsymbol{\Psi} \neq 0$. The probability of a test's detecting that $\boldsymbol{\psi}$ is not zero is greater with a planned than with an unplanned comparison on the same means. In other words, for any particular comparison, the test is more powerful when the comparison is planned than when it is post hoc.

Or stated differently, with a planned comparison, there is less probability of finding a spurious significance by chance. Considering these points, it appears that Wollert et al. (1981) used statistics adequate to test the causal locus 
hypothesis.

Another explanation for their findings might be that the tasks were not important enough to effect the predicted mood changes. However, highly significant differences in mood were found between success and failure subjects, suggesting that the tasks were important to them.

It is possible that the attribution inductions were too early in the experiment to effect the predicted mood variations. Attributions were induced only before the task. Posttask manipulation check did show the intended differences in attributions between induction groups. Clearly subjects at least remembered which attributions to make. The question remains "Were these different attribution inductions sufficiently salient to affect mood?" As the self-serving biases hypothesis (Kuiper, 1978) suggests, nondepressed subjects tend to assume responsibility for success but deny responsibility for failure. It is possible, then, that outcomes weakened the effect of dissonant pretask attribution inductions for some subjects.

Finally, it may be that the causal locus hypothesis itself is a weak hypothesis. Mood variation, when it occurs, may not be due to attribution but rather to the cognitive processes which specifically involve self-evaluation. In some cases, evaluative process may be associated with attribution. For example, a person may accept that she caused a failure (an attribution) and blame herself (a selfevaluation) for that outcome. This person would then feel 
depressed. In other cases evaluative processes may not be associated with attributions. For example, the woman may attribute the failure to herself, and not blame herself, and consequently not become depressed. This is not an unprecedented distinction to make. In fact, it has formed the basis of a theory of psychotherapy which has become widely accepted (EIlis, 1979).

Thus, when experiments do show a relationship between attributions and mood, it may be the self-evaluations implied by the attributions and not the attributions themselves which affected mood. Conceivably, self-evaluations could affect mood independently of attributions. This forms the core of what will be called the self-evaluational hypothesis. The present study was devised to explore particularly the last two issues. Two hypotheses were explored. First, the causal locus hypothesis was again tested using a design similar to that used by Wollert et al. (1981) in Experiment 2 , but with individual administration. To minimize the salience of any self-serving biases, attributions were induced throughout the experiment. Further, equal numbers of men and women participated in each condition.

On the basis of the causal locus hypothesis, it was predicted that attribution and outcome would interact such that internal attributions for failure and external attributions for success would cause more negative postoutcome mood than external attributions for failure and internal attributions 
for success. Analysis of variance of the moods would be used to test for the interaction. Planned comparisons of the mood scores for these four conditions would test the predicted inequality.

In addition, the self-evaluational hypothesis was explored. This hypothesis holds that evaluation about oneself in relation to events affects mood, and may do so independently of attributional content. For example, people experience elevated mood when they encounter positive events and give themselves credit for this or in some way affirm themselves. They experience dysphoria when they encounter negative events and blame themselves for these events.

On the basis of the self-evaluational hypothesis, the following predictions were made.

1. Credit or blame would be correlated with mood. This would be particularly evident for depression. Credit for successful outcome would be negatively correlated with depression; blame for failing outcome would be positively correlated.

2. If attribution were also correlated with these negative moods, it would necessarily be confounded with credit or blame. Thus, if the effect of credit or blame were removed (by partial correlation) the relationship between attribution and mood would be nonsignificant.

3. Finally, if attribution and credit/blame were 
uncorrelated with each other, attribution would be uncorrelated with mood while credit or blame would be correlated with mood. 


\section{CHAPTER II}

IETHOD

Subjects

Subjects were 49 female and 50 male undergraduate students enrolled in introductory psychology courses at Portland State University. All subjects earned extra course credit for participating. Data for 1 female and 2 male subjects were rejected because these subjects realized they had received bogus feedbrck.

Tasks and Naterials

The Word Association Task. The experiment used a modified version of a word association task previously used by Kuiper (1978) to assess attributions made by depressives. The task required subjects to indicate which of two words was more often associated by other people with a given stimulus word. Given a stimulus word such as "ocean", for instance, subjects were asked to decide whether the more common associate was "waves" or "deep". In actuality, the associate words were chosen on the basis that they be associated with the stimulus word with equal likelihood (Bilodeau \& Howell, 1965).

The word association task included five trials (Appendix A). Each trial consisted of eight association items typed 
on an 8 inch $(20 \mathrm{~cm})$ by 11 inch $(28 \mathrm{~cm})$ paper, entitled "Word Association Questionnaire". Below the heading was one of three one-sentence instructions, depending on the induction group. Internal attribution subjects were instructed to "Use your best ability to predict which word most people associate with each stimulus word." External attribution subjects were asked to "Try and guess which word most people associate with each stimulus word." Neutrals were asked to "Choose the word that most people associate with each stimulus word." At the bottom of each trial were two boxes beside the word "outcome". One was labeled "succeed ( 5 or more correct)" and the other was labeled "failure ( 4 or less correct)". A sentence was typed below these boxes on the last (fifth) trial for internal and external subjects only. These were: (internal) "You have completed this test of your ability to predict other peoples' responses." and (external) "You have completed the guessing task."

Pretask Attribution Induction and Instructions. Forms entitled "The Word Association Questionnaire" with separate paragraphs labeled "Description" and "Instructions" were used to explain the task and induce attributions before the task (Appendix B). Three different description paragraphs were used to induce subjects to perceive different levels of control over outcome. For internal induction, the description prepared subjects to predict the more frequently given 
response, emphasizing that skill was necessary to succeed on the task. For external induction, the description prepared subjects to guess the more frequently given response, emphasizing the importance of luck and other uncontrollable factors. The neutral (no induction) attribution description prepared subjects to simply choose the more frequently given response.

In the instructions paragraph, subjects were told how to record responses on the questionnaire. Two examples were given. This paragraph was identical for all groups. liood Assessment Checklists. The depression, anxiety, and hostility adjective checklists used by Wollert et al. (1981) were used in the present study to assess mood after the task. These can be found in Appendix $C$.

Self-evaluation measure. On an 8 inch $(20 \mathrm{~cm})$ by 3 inch $(7 \mathrm{~cm})$ paper one of two questions was typed (Appendix D). For success subjects the question was "How much do jou take credit for and congratulate yourself for your level of performance?" Failure subjects were asked "How much do you blame Jourself for your level of performance?" Below the question was a horizontal line labeled with equally spaced numerals 1 through 10. These verbal anchors were typed below the following numerals: (1) Not at all; (3) Somewhat; $(5-6)$ in between; (8) largely; and (10) a great deal. Posttask manipulation check. On the same sized paper the following question was asked "To what extent was your 
performance under your control?" Below this question was a scale identical to that used above (Appendix $\mathrm{E}$ ).

\section{Procedure}

An equal number of males and females were randomly assigned to one of two outcome conditions, success and failure, and to one of three attribution induction conditions, internal, external, and no induction (neutral). Sixteen subjects participated in each of these six conditions.

The experimenter met with each subject individually. After the subject was seated, the experimenter read a prepared script (Appendix F) which introduced the word task. The experimenter then provided the appropriate "Description" and "Instructions" and read these to subject while subject followed along. The subject was then given the Word Association Questionnaire. Before each trial, the experimenter read the one sentence pretrial instructions to the subject. After the trial, the experimenter ostensibly referred to an answer sheet and "scored" each item on the trial, checking the "success" or "failure" box at the bottom of the trial. In actuality, the items which the subject failed were predetermined for both outcomes (Appendix $G$ ). Subjects in the success condition received success feedback on four of the five trials. Those in the failure outcome succeeded on only one trial.

If the subject was in the internal or external induction group, the experimenter then read the typed sentence at the 
bottom of the last trial. Following this, the experimenter read the appropriate internal or external posttask description (Appendix F), thereby reinducing the appropriate attribution.

Regardless of induction group, the subject was then given the three mood assessment instruments, with the "score" from the Word Association Questionnaire recorded at the top of the first sheet.

Finally, the experimenter presented the self-evaluation measure and then the posttask attribution manipulation check. In each case, the experimenter read the question and instructed the subject to circle the chosen answer.

After the materials were retrieved, the subject was questioned to determine what understanding, if any, he or she had of the hypothesis or suspicions about feedback on the Word Association Questionnaire. The subject was then debriefed and thanked for participation. Data for three subjects were discarded because these subjects perceived they had received bogus feedback. 


\section{CHAPTER III}

\section{RESULTS}

\section{Manipulation Check}

Scores from the postask question "To what extent was your performance under your control?" were analyzed to determine the effectiveness of pretask, pretrial, and posttask attribution inductions. Interestingly, overall control scores for internal and neutral conditions were identical. Thus the analysis of these scores was restricted to the two induction groups, internal and external. A two by two by two (outcome by sex by induction) analysis of variance (ANOVA) established significant differences $(\underline{F}(1,95)=4.45, \underline{p}(.05)$ between induction groups. No other main effects or interactions were significant at $p<.05$. As expected, subjects in the external induction groups for both outcomes reported significantly less control over their performance than did subjects in the internal groups. Means and standard deviations are reported in Table $I$.

Attribution inductions also minimized self-serving biases within internal or external conditions. That is, internal/success subjects did not report significantly more control than did internal failure subjects. External/failure subjects did not report significantly less control than did 


\section{TABLE I}

MEAND AND STANDARD DEVIATIONS ${ }^{2}$ FOR MOOD, CONTROL, AND CREDIT OR BLAME CHECKLISTS

Success

Induction Inter- Exter- Neut-
Failure

Inter- Exter- Neut-
nal nal $(n=16) \quad(n=16) \quad(n=16)$

Hoods

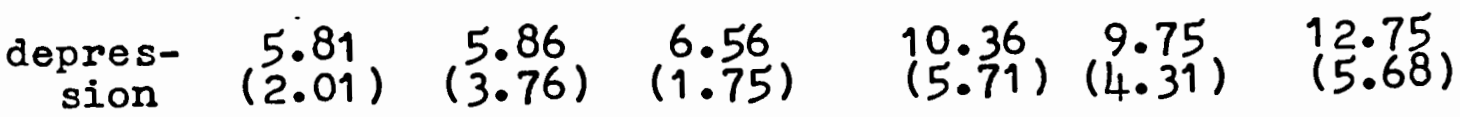

$\begin{array}{ccccccc}\begin{array}{c}\text { hostil- } \\ \text { ity }\end{array} & \left(\begin{array}{l}5.69 \\ 3.26)\end{array}\right. & \left(\begin{array}{l}5.13 \\ 2.60)\end{array}\right. & \left(\begin{array}{l}6.00 \\ 2.13)\end{array}\right. & \left(\begin{array}{l}5.94 \\ 2.86)\end{array}\right)\left(\begin{array}{l}7.25 \\ 4.40)\end{array}\right. & (3.06 \\ 3.89)\end{array}$

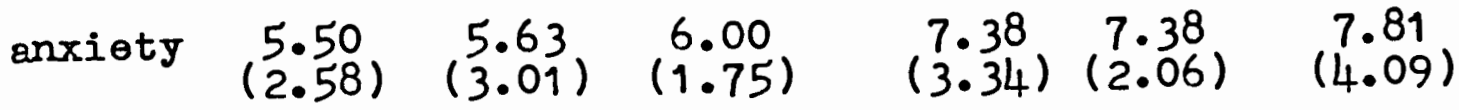

$\begin{array}{lllllll}\text { Control } & 6.44 & 5.13 & 7.19 & 6.63 & 4.56 & 5.86 \\ (2.09) & (2.55) & (2.17) & (2.53) & (3.18) & (2.85)\end{array}$

Credit

$\begin{array}{ccc}6.63 & 5.19 & 6.75 \\ (2.06) & (2.61) & (1.98)\end{array}$

Blame

$\left.\begin{array}{lll}3.56 & 2.50 \\ (2.10) & (1.89) & (2.94 \\ 1.29\end{array}\right)$

${ }^{a}$ Standard deviations are in parentheses. 
external/success subjects. In contrast, a greater, though still not statistically significant self-serving biases effect was found in the neutral condition, where attributions were not induced. Subjects in the neutral group who succeeded reported more control over outcome than those who failed $(\bar{x}=7.19$ vs. $\bar{x}=5.86)$.

\section{Analysis of Mood}

The mood data were first analyzed by a two by two by three (outcomes by sex by induction groups) ANOVA. As expected, significant main effects for outcomes were found on the depression $(\underline{F}(1,95)=32.77, \mathrm{p}<.001)$ and anxiety $(\underline{F}(1,95)=9.32, \underline{p}<.005)$ scales. The main effects for outcome were marginally significant on the hostility scale $(\underline{F}(1,95)=2.86, p=.09)$. No significant main effects were found for attribution or sex on any of the mood scales and no interactions appeared. Means and standard deviations for the mood checklists are reported in Table $I$.

A priori planned comparisons were used to test the causal locus hypothesis. The hypothesis holds that mean mood scores will be more negative (higher) for subjects in the internal/failure and external/success conditions than for those in the external/failure and internal/success conditions. None of the comparisons on the three mood scales supported the hypothesis (all F's $<1.0$ ).

Pearson correlations between mood measures within each condition were then computed (Table II). Correlation 
CORRELATIONS BETWEEN MOOD CHECKLISTS WITHIN CONDITIONS

\begin{tabular}{|c|c|c|c|c|c|c|}
\hline \multirow[b]{2}{*}{ Induction } & \multicolumn{3}{|c|}{ Success } & \multicolumn{3}{|c|}{ Failure } \\
\hline & $\begin{array}{l}\text { Inter } \bar{a} \\
\text { nal }\end{array}$ & $\begin{array}{c}\text { Exter- } \\
\text { nal }\end{array}$ & Neu- & $\begin{array}{l}\text { Inter- } \\
\text { nal }\end{array}$ & $\begin{array}{l}\text { Exter- } \\
\text { nal }\end{array}$ & $\begin{array}{l}\text { Nou- } \\
\text { tral }\end{array}$ \\
\hline $\begin{array}{c}\text { Depression/ } \\
\text { Anxiety }\end{array}$ & $.76 *$ & $.71 *$ & .22 & -.16 & $.60 \%$ & .17 \\
\hline $\begin{array}{c}\text { Depression/ } \\
\text { Hostility }\end{array}$ & $.69 *$ & .41 & $\cdot 37$ & -.02 & $.49 *$ & .26 \\
\hline $\begin{array}{l}\text { Anxiety/ } \\
\text { Hostility }\end{array}$ & .48 & $.52 *$ & $\cdot 36$ & .22 & $.71 *$ & $.81 *$ \\
\hline
\end{tabular}

$a_{n}=76$ for each group.

*p<. 05, two tailed. 
coefficients between depression and anxiety measures ranged from -.16 to +.76 . Three of these coefficients were significant. Correlations between depression and hostility ranged from -.02 to +.69 , with two significant values. Anxiety and hostility coefficients ranged from +.22 to +.81 , and were significant in three groups.

Correlational Analysis of the Relationship between Mood, Attribution, and Self-evaluation

To determine the relationship between attribution and mood within groups, Pearson correlations were computed between the three mood scales and the posttask attribution questionnaire (control) (Table III). Significant negative correlations were found between the mood scales and control in the internal/success froup, and between depression and control for the external/success group. These results indicate that subjects with greater sense of control experienced less negative mood in the above two conditions. No other correlations between a mood scale and control were significant. Specifically, there appeared to be no relationship between attribution and mood for any of the failure outcome groups.

Similarly, to determine the relationship between selfevaluation and mood within groups, correlations between credit (success groups) or blame (failure groups) and the mood scales were computed (Table IV). Significant negative correlations were found between credit and mood for internal/ 


\section{TABLE III}

CORRELATIONS BETWEEN MOOD CHECKIISTS AND CONTROL CHECKIISTS

\begin{tabular}{|c|c|c|c|c|c|c|}
\hline \multirow[b]{2}{*}{ Induction } & \multicolumn{3}{|c|}{ Success } & \multicolumn{3}{|c|}{ Failure } \\
\hline & $\begin{array}{c}\text { Inter- } \\
\text { nal }\end{array}$ & $\begin{array}{c}\text { Exter- } \\
\text { nal }\end{array}$ & $\begin{array}{l}\text { Nou- } \\
\text { tral }\end{array}$ & $\begin{array}{c}\text { Inter- } \\
\text { nal }\end{array}$ & $\begin{array}{c}\text { Exter- } \\
\text { nal }\end{array}$ & $\begin{array}{c}\text { Neu- } \\
\text { tral }\end{array}$ \\
\hline $\begin{array}{c}\text { Depression/ } \\
\text { Control }\end{array}$ & $-.41 *$ & $-.47 *$ & -.10 & .04 & -.34 & .15 \\
\hline $\begin{array}{r}\text { Hostility/ } \\
\text { Control }\end{array}$ & $-.49 \%$ & -.28 & .07 & .06 & -.03 & -.04 \\
\hline $\begin{array}{l}\text { Anxiety/ } \\
\text { Control }\end{array}$ & $-.55 \%$ & -.33 & -.12 & -.13 & -.01 & -.04 \\
\hline
\end{tabular}

Kpr.05, one tailed. 
TABLE IV

CORRELATIONS BETWEEN MOOD CHECKLISTS AND CREDIT OR BLAME CHECKLISTS

\begin{tabular}{|c|c|c|c|c|c|c|}
\hline \multirow[b]{2}{*}{ Induction } & \multicolumn{3}{|c|}{ Success } & \multicolumn{3}{|c|}{ Failure } \\
\hline & $\begin{array}{c}\text { Inter- } \\
\text { nal }\end{array}$ & $\begin{array}{c}\text { Exter- } \\
\text { nal }\end{array}$ & $\begin{array}{l}\text { Neu- } \\
\text { tral }\end{array}$ & $\begin{array}{c}\text { Inter- } \\
\text { nal }\end{array}$ & $\begin{array}{c}\text { Exter- } \\
\text { nal }\end{array}$ & $\begin{array}{l}\text { Neu- } \\
\text { tral }\end{array}$ \\
\hline $\begin{array}{c}\text { Depression } \\
\text { Credit }\end{array}$ & $-.51 *$ & -.32 & -.03 & & & \\
\hline
\end{tabular}

$\begin{gathered}\text { Hostility/ } \\ \text { Credit }\end{gathered} \quad-.62 * \quad .06 \quad .33$

$\begin{array}{llll}\text { Anxiety } / & & & \\ \text { Credit } & -.48 * & -.16 & .08\end{array}$

Depression/

Blame

$.45 * \quad .65 * \quad-.06$

Hostility/.

Blame

$.34 \quad .14 \quad .11$

Anxiety/

Blame

$-.14 \quad .22 \quad .39$

$* p<.05$, one tailed. 
success subjects, indicating that the more credit these subjects took for their success, the less negative mood they experienced. Blame and depression were positively correlated in the internal/ and external/failure groups, indicating that subjects in these groups who blamed themselves more showed more negative mood.

It thus appeared that both dimensions, self-evaluation and attribution, were related to mood, particularly to depression, for success outcome, but only self-evaluation was related to mood in the failure outcome. Further correlational analysis ( $T a b l e V$ ) revealed that in the success condition these dimensions were also highly correlated with each other, ie. confounded. The credit/control correlations were significant in each of the three success groups. In the failure condition, however, the two dimensions were very independent. The blame/control correlations ranged from -.06 to +.13 .

To determine the strength of relationship between each dimension and mood while removing the effects of the other dimension, partial correlations were computed (Tables VI, VII). Where the two dimensions were confounded (success), partial correlations revealed no significant relationship between either dimension and depression. Where the dimensions were independent (failure), partial correlations revealed significant relationships between self-evaluation (blame) and depression but not between attribution and depression. No other significant partial correlations were found. 
TABLE V

CORRELATIONS BETWEEN CONTROL AND CREDIT OR BLAME

Success

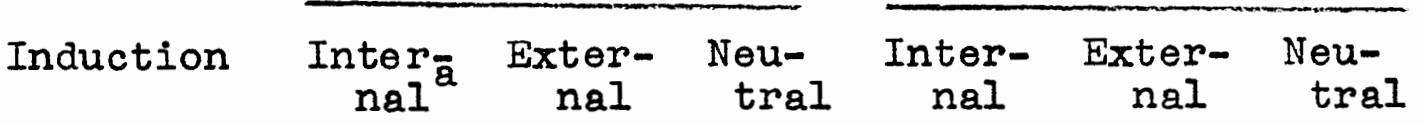

Control/

Credit
$.63 *$

$.78 \%$

$.83 *$

Control/

Blame

$-.06 \quad-.06$

.13

$a_{n}=16$ for each group.

*. .05, two tailed. 
PARTIAL CORRELATIONS BETWEEN DEPRESBION AND CREDIT OR BLAIE, CONTROLLING FOR CONTROL

\begin{tabular}{|c|c|c|c|c|c|c|}
\hline \multirow[b]{2}{*}{ Induction } & \multicolumn{3}{|c|}{ Success } & \multicolumn{3}{|c|}{ Failure } \\
\hline & $\begin{array}{c}\text { Inter- } \\
\text { nal }\end{array}$ & $\begin{array}{c}\text { Exter- } \\
\text { nal }\end{array}$ & $\begin{array}{l}\text { Neu- } \\
\text { tral }\end{array}$ & $\begin{array}{c}\text { Inter- } \\
\text { nal }\end{array}$ & $\begin{array}{c}\text { Exter- } \\
\text { nal }\end{array}$ & $\begin{array}{l}\text { Neu- } \\
\text { tral }\end{array}$ \\
\hline $\begin{array}{c}\text { Depression/ } \\
\text { Credit }\end{array}$ & -.37 & .08 & .09 & & & \\
\hline $\begin{array}{c}\text { Depression/ } \\
\text { Blame }\end{array}$ & & & & $.45 *$ & $.67 *$ & -.08 \\
\hline
\end{tabular}

TABLE VII

PARTIAL CORRELATIONS BETWEEN DEPRESSION AND CONTROL, CONTROLLING FOR CREDIT OR BLAME

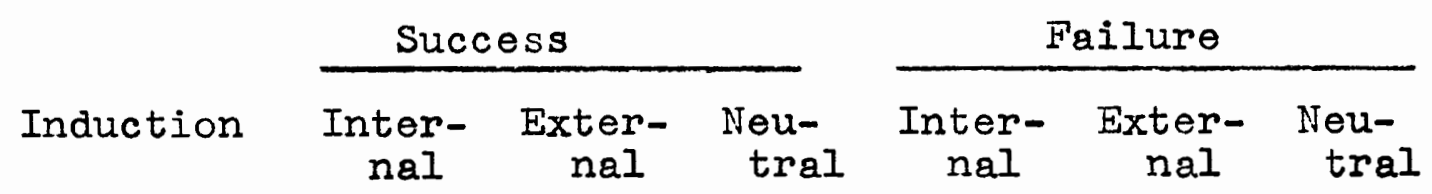

Depression/

$\begin{array}{lllllll}\text { Control } & -.12 & -.33 & -.13 & -.02 & -.39 & .16\end{array}$

$$
\begin{aligned}
& a_{n}=16 \text { for each group. } \\
& i p<.05 \text {, one tailed. }
\end{aligned}
$$




\section{CHAPTER IV}

\section{DISCUSSION}

\section{Causal Locus Hypothesis}

This experiment was conducted in part to test the causal locus hypothesis. This hypothesis asserts that internal attributions for failure and external attributions for success cause more negative postoutcome moods than external attributions for failure and internal attributions for success. In this study outcome did affect mood, but attributions did not. Further, attributions did not interact significantly with outcome to affect mood. The results of this experiment, therefore, did not support the causal locus hypothesis.

The design of this study was similar to that used by Wollert et al. (1981) (Experiment 2 and 3) in that it used direct manipulation of attribution and outcome to assess their affects on mood. It differed in some respects. This study went the furthest in assuring that the intended attributions were induced. Internal and external subjects heard a total of eight inductions, seven of which they read at the same time. Postoutcome manipulation checks demonstrated the effectiveness of these inductions. Nevertheless, mood was not affected as hypothesized. These results are 
consistent with those obtained by Wollert et al. (1981).

The study also sought to assess the effect of sex differences on the other variables. Equal numbers of men and women were assigned to each condition. No main effects and no interactions were found for sex.

The most important theoretical implication of this study for the causal locus hypothesis is found in the contrast between the very strong effect of success and failure upon mood with no effect for internal or external attributions. In short, events had a definite impact on mood, but this impact was not affected by internal or external attributions.

It is possible that the strong effect found for outcome was due to the demands subjects may have felt from the experimenter. If the tasks were, in fact, not important to the subjects, they may'recorded moods which they thought were appropriate or expected: positive moods for success or negative moods for failure. Since the locus of control variable would be less obvious to naive subjects, it would not have influenced the subjects' perception of experimenter demand. Future tests of the causal locus hypothesis might utilize a separate setting and, perhaps, different experimenter during the mood assessment phase. It is also suggested that moods be assessed after a short break to further minimize possible effects of experimenter demand.

Since the issue of experimenter demand raises a question about the meaningfulness of the word task, the indicated 
rejection of the causal locus hypothesis is also called into question. However, further analysis (below) strongly suggests that the causal locus hypothesis could not adequately explain mood variation.

The Self-evaluational Hypothesis

Analysis of the relationship between both dimensions, attribution and self-evaluation with depression presented a revealing pattern. Generally, when attributions were induced (internal, external) both dimensions were related to depression in the success outcome, but only self-evaluation was related to depression in the failure outcome. Neither dimension was related to depression in the noninduction conditions. Finally, anxiety and hostility were generally less related to the dimensions than was depression.

How can this pattern be explained? First of all, attribution and self-evaluation were confounded in the success outcome, but in the failure outcome they were independent. Partial correlations established that almost all of the variation in depression in the failure outcome induction groups was accounted for by self-evaluation. In other words, where it was possible to isolate dimensions, there was an effect for self-evaluation but not for attribution. This strongly supports our hypothesis that self-evaluation is necessary for attribution to affect mood.

This explanation accounts for the weaker relationship found between the dimensions and anxiety or hostility. The 
specific self-evaluation measures used, credit or blame, were most relevant to depression. Other self-evaluations are likely to be more related to anxiety or hostility. It also explains the negligible relationship between these dimensions and depression in the noninduction groups. Attributions made by these subjects did not imply credit or blame, hence they did not mobilize the self-evaluation process. Consequently, mood was not affected.

The causal locus hypothesis is re-examined in light of these findings. That hypothesis held that mood would be affected by attribution. This experiment found, however, that attribution by itself was not related to mood for any of the failure outcomes. Only when self-evaluations were mobilized were moods affected. In short, where attributions of control imply credit for success or blame for failure, mood will be affected in accord with the causal locus hypothesis. Where attribution for control and credit for succuss or blame for failure are independent, mood will be related to the evaluative dimension, not to the attributional dimension.

These findings call into question major hypotheses which hold that the internal/external dimension of attribution influences mood. For instance, weiner et al. (1971) maintained that internal attributions for success or failure produce more positive or more negative affect respectively than external attributions. This difference was not supported 
by our data. It may obtain if the attributions activate specific self-evaluations. But attributions did not necessarily activate self-evaluations, particularly in the failure outcome.

Seligman's learned helplessness model of depression (Abramson et al., 1978) holds that attributing helplessness to internal factors leads to lowered self-esteem and consequently to depression, but attributing helplessness to external factors does not. The data suggest this would obtain only if those attributions activate specific selfevaluations relevant to self-esteem and depression. 
REFERENCE LIST

Abramson, L. Y., Seligman, M. E. P., \& Teasdale, J. D. Learned helplessness in humans: Critique and Reformulation. Journal of Abnormal Psychology, 1978, 87, 49-74.

Bilodeau, E. A., \& Howell, D. C. Free Association Norms by Discrete and Continuous Methods. Washington, D.C.: U. S. Department of the Navy, Office of Naval Research, 1965.

Ellis, A. E., \& Harper, R. A. A New Guide to Rational Living. North Hollywood: Wilshire Book Co., 1979.

Golin, S., Sweeney, P. D., \& Shaeffer, D. E. The causality of causal attributions in depression: A crossedlagged panel correlational design. Journal of Abnnormal Psychology, 1981, 90, 14-22.

Harvey, D. M. Depression and attributional style: Interpretations of important personal events. Journal of Abnormal Psychology, 1981, 90, 134-142.

Hays, W. I. Statistics for the Social Sciences. New York: Holt, Reinhart, \& Winston, 1973.

Klein, D. C., Fencil-Morse, E., \& Seligman, r. E. P. Learned helplessness, depression, and the attribution of failure. Journal of Personality and Social Psychology, 1976, 33 , $508-516$.

Kuiper, N. Depression and causal attributions for success and failure. Journal of Personality and Social Psychology, $1978,36,236-246$.

Pittman, N. L., \& Pittman, T. S. Effects of amount of helplessness training and internal-external locus of control on mood and performance. Journal of Personality and Social Psychology, 1979, 37, 39-47.

Rehm, L. P. Mood, pleasant events, and unpleasnat events: Two pilot studies. Journal of Consulting and Clinical Psychology, 1978, 46, 854-859.

Rizley, R. Depression and distortion in the attribution of causality. Journal of Abnormal Psychology, 1978, 87, $32-48$. 
Rotter, J. B. Generalized expectancies for internal versus external control of reinforcement. Psychological Monographs, 1966, 80 (1, Whole No. 609).

Seligman, M. E. P., Abramson, L. Y., \& Semmel, A. Depressive attributional style. Journal of Abnormal Psychology, $1979,88,242-247$.

Weiner, B., Frieze, I., Kukla, A., Reed, I., Rest, S. A., \& Rosenbaum, R. M. Perceiving the Causes of Success and Failure. New York: General Learning Press, 1971.

Wener, A. E., \& Rehm, L. P. Depressive affect: A test of two behavioral hypotheses. Journal of Abnormal Psychology, $1975,84,221-227$.

Wollert, R. W., Helnrich, L., \& Wood, D. Causal attributions and normal mood variations: Unpublished paper presented at the Annual Meeting of the Western Psychological Association, Los Angeles, April, 1981.

Wortman, C. B., Panciera, I., Shusterman, I., \& Hibscher, J. Attributions of causality and reactions to uncontrollable outcomes. Journal of Experimental Social Psychology, 1976, 12, 301-316.

Zuckerman, M. Development of affect adjective checklists for measurement of anxiety. Journal of Consulting Psychology, $1960,24,457-462$. 


\section{APPENDIX A \\ Word Association Questionnaire \\ Form 1}

Chair

Use your best ability to predict which word most people associate with each stimulus word.

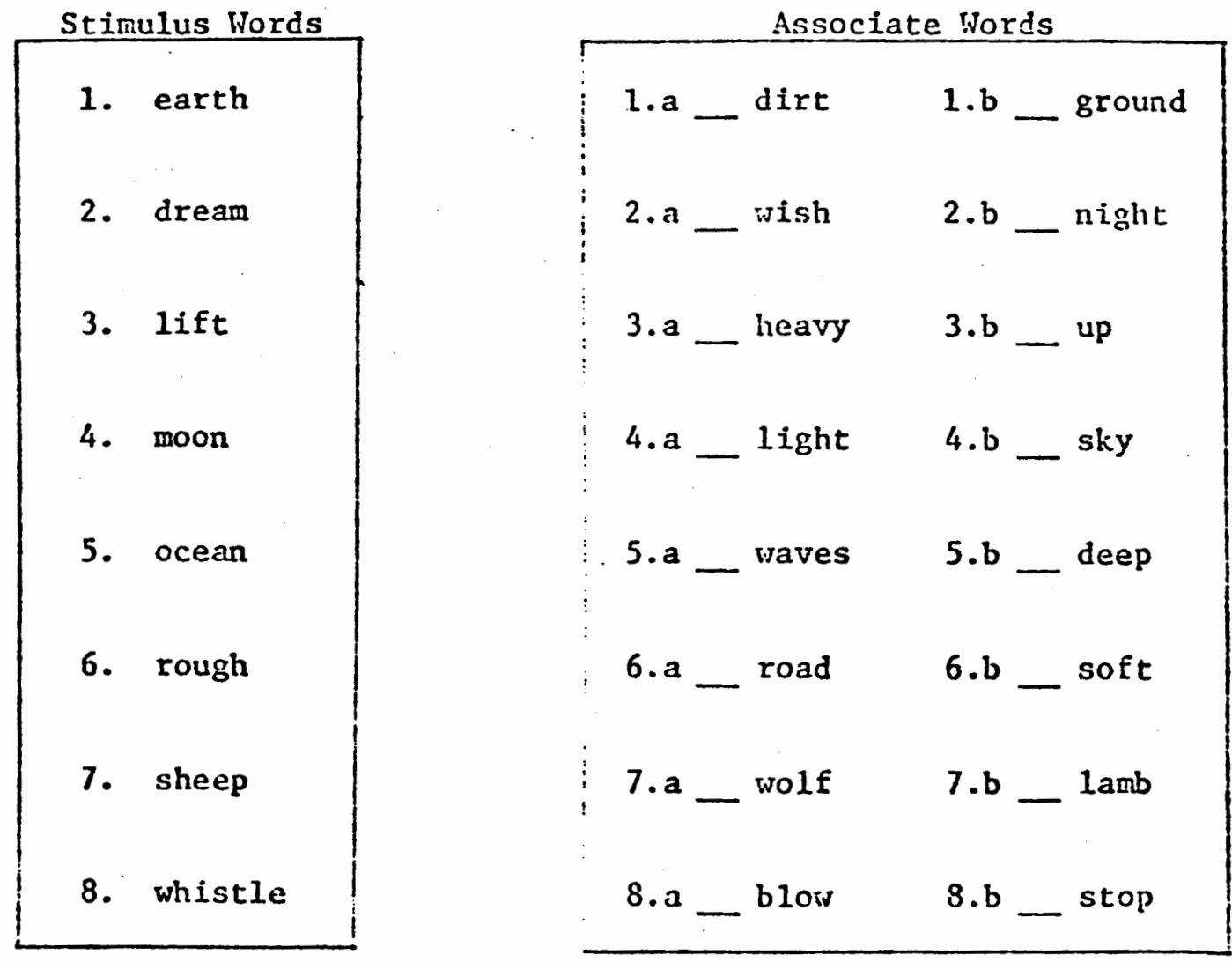

Cutcome: $\square$ succeed (5 or more correct)

$\square$ fail ( 4 or less correct) 
Word Association Questionnaire

Form 2

Chair

Use your best ability to predict which rord most people associate with
each stimulus word.

Stinulus Words

1. anger

2. cabbage

3. hand

4. house

5. Loud

6. mountain

7. people

8. stove
Associate Words

\begin{tabular}{|lc|}
\hline $1 . a-$ fear & $1 . b-$ hate \\
$2 . a-$ green & $2 . b-$ food \\
$3 . a-$ ring & $3 . b-$ glove \\
$4 . a-$ window & $4 . b-$ roof \\
$5 . a-$ quiet & $5 . b-$ noisy \\
$6 . a-$ valley & $6 . b-$ top \\
$7 . a-$ places & $7 . b-$ animals \\
$8 . a-$ varm & $8 . b-$ fire
\end{tabular}

Outcome: $\square$ succeed (5 or more correct)

$\square$ fail (4 or less correct) 
Word Association Questionnaire

Form 3

Chair

Use your best ability to predict which word most people associate with each stimulus rord.

Stimulus Uords

1. baby

2. fruit

3. head

4. needle

5. priest

6. river

7. salt

8. daugheer
Associate Dords

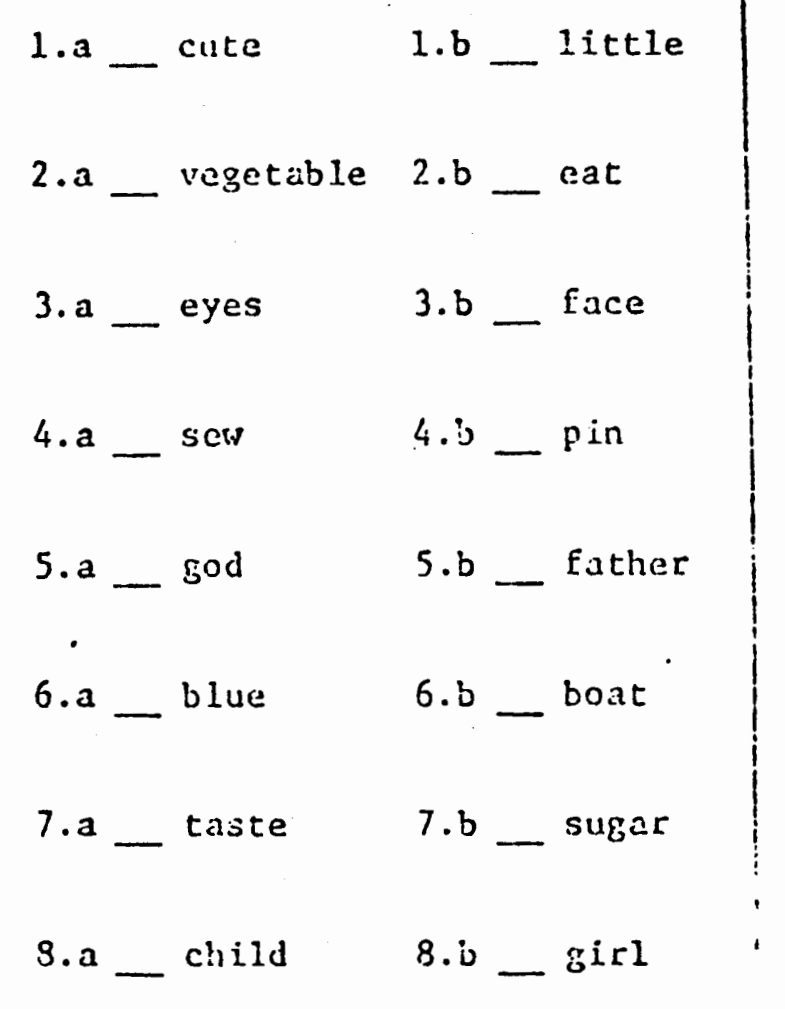

Outcone: $\square$ succeed (5 or more correct)

$\square$ fail ( 4 or less correct) 
Word Association Questionnaire

Form 4

Chair

Use your best ability to predict which word most people associate with each stimulus rord.

\section{Stimulus Words}

1. bed

2. dance

3. hunger

4. music

5. wouth

6. scissors

7. table

8. farm
Associate Words

\begin{tabular}{|lc|}
\hline$. a-$ sheet & $1 . b$ - blanket \\
$2 . a-$ play & $2 . b$ - party \\
$3 . a-$ eat & $3 . b-$ pain \\
$4 . a-$ sound & $4 . b-$ song \\
$5 . a-$ tongue & $5 . b-$ lips \\
$6 . a-$ cloth & $6 . b-$ paper \\
$7 . a-$ eat & $7 . b-$ food \\
$8 . a-$ cow & $8 . b-$ house
\end{tabular}

Outcome: $\square$ succeed (5 or more correct)

$\square$ fail ( 4 or less correct) 
Word Association Questionnaire

Form 5

Chair

Ose your best ability to predict which word most people associate with each stimulus word.

Stimulus Words

1. bite

2. fire

3. curtain

4. hospital

5. paper

6. rug

7. screen

8. trunk
Associate Vords

\begin{tabular}{|c|c|c|c|}
\hline $1 . a$ & tooth & $1 . b$ & _ chew \\
\hline $2 . a-$ & smoke & $2 . b$ & _ flame \\
\hline $3 . a-$ & drapes & $3 . b$ & $-\operatorname{rod}$ \\
\hline $4 . a$ & bed & 4.6 & _ sickness \\
\hline $5 . a$ & pencil & $5 . b$ & _ pen. \\
\hline 6.a - & floor & $6 . b$ & - carpet \\
\hline $7 . \dot{a}$ & picture & 7.6 & _ door \\
\hline 8.a & car & $8 . \mathrm{b}$ & - tree \\
\hline
\end{tabular}

Outcome: $\square$ succeed (5 or more correct)

$\square$ fail (4 or less correct)

You have completed this test of your ability to predict other penples' responses. 
Word Association Que:stionnaire

Form 1

Chair

Try to guess which word most people associate with each stimulus word.

Stimulus Words

1. earth

2. dream

3. 1ift

4. moon

5. ocean

6. rough

7. sheep

8. whistle
Associate Hords

1.a dirt

1.b _ ground

2.a - wish

2.b night

3.a heavy

$3 . b$ up

4.a light

4.b _ sky

$5 . a$ waves

$5 . b$ deep

$6 . a$ road

$6 . b-\operatorname{soft}$

$7 . a$ wolf

$7 . b-1 a n b$

8.a blow stop

Outcome:

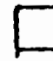
succeed (5 or more correct)

$\square$ fail ( 4 or less correct) 
Hord Association Questionnaire

Form 2

Chair

Try to giess which word most people associate with each stimulus word.

Stimulus Words

1. anger

2. cabbage

3. hand

4. nouse

5. loud

6. Ecuntain

7. people

8. Stove

Outcona:
Assuciate lords

\begin{tabular}{|lc|}
$1 . a-$ fear & $1 . b-$ hate \\
$2 . a-$ green & $2 . b-$ food \\
$3 . a-$ ring & $3 . b-$ glove \\
$4 . a-$ winder & $4 . b-$ roof \\
$5 . a-$ quiet & $5 . b-$ noisy \\
$5 . a-$ valley & $6 . b-$ top \\
$7 . a-$ places & $7 . b-$ aninals \\
$8 . a-$ varm & $8 . b-$ fire \\
\hline
\end{tabular}

1.3

$\square$ fail (4 or less correct) 


\section{liord Association Questionnaire}

Form 3

\section{Chair}

Try to guess which rord most people associate with each stimulus word.

Stimulus Vords

1. baby

2. fruit

3. head

4. needle

5. priest

6. river

7. salt

8. daughter
Associate Uords

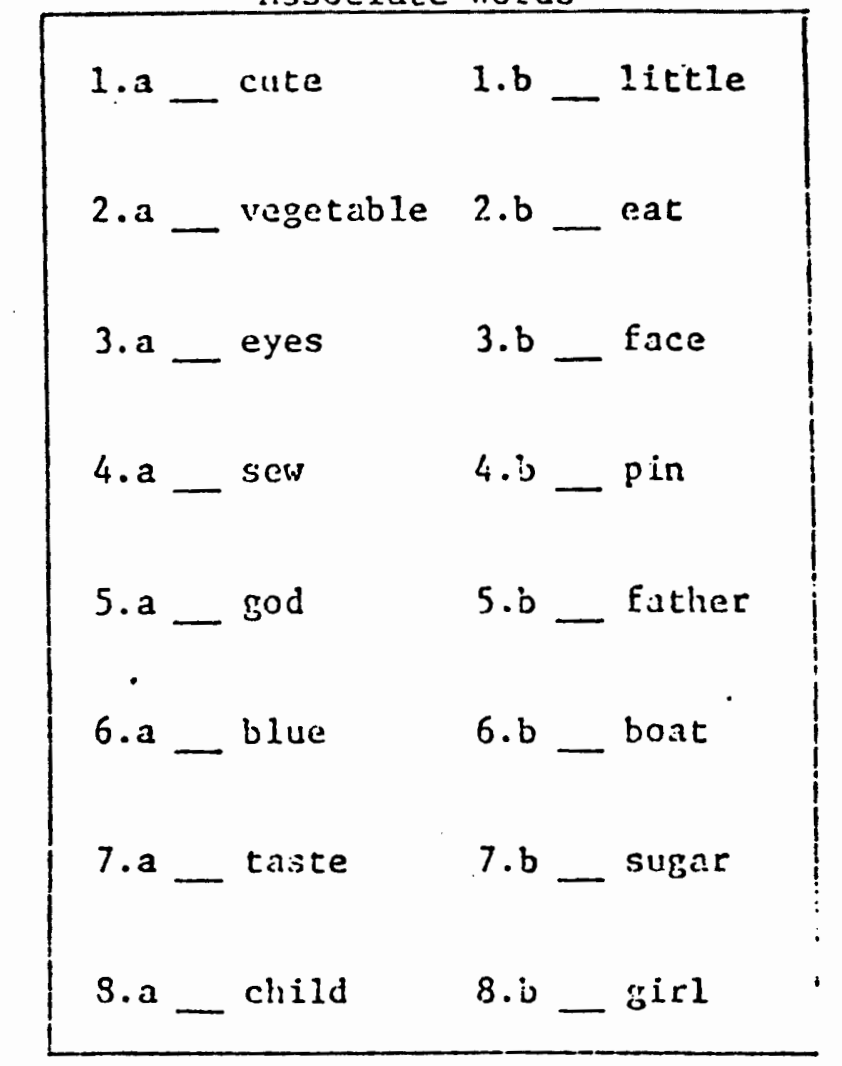

Outcome: $\square$ succeed (5 or more correct)

$\square$ fail ( 4 or less correct) 
Lurd Aussediation Qucsitiomatre

Forn 4

Chair

Try to guess which word most people associate with each stimulus word.

Stimulus Words

1. bed

2. dance

3. hunger

4. rusic

5. routh

6. scissors

7. tabic

8. farm
Assoninte linrds

\begin{tabular}{|c|c|c|c|}
\hline $1 . \mathrm{a}$ & sheet & I.b & blanket \\
\hline $2 . a$ & play & $2 . b$ & party \\
\hline $3 . a$ & eat & $3 . b$ & pain \\
\hline $4 . a$ & sound & $4 . b$ & song \\
\hline $5 . a$ & tungue & 5.6 & במpin \\
\hline $6 . a$ & cloth & $6 . b$ & Pis \\
\hline $7 . a$ & eat & 7.0 & [l:u. 1 \\
\hline 8.3 & $\cos$ & 8.5 & hinse \\
\hline
\end{tabular}

Outcone: $\square$ succeed (5 or more correct)

$\square$ fail ( 4 or less correct) 
Wurd Association Questionnatre

Form 5

Chair

Try to guess which word most people associate with each stimulus word.

Stimulus Words

1. bite

2. fire

3. curtain

4. hospital

5. paper

6. rug

7. screen

8. trunk

Outcome: $\square$ succeed (5 or more correct)

$\square$ fail (4 or less correct)
Associate fords

1.a - tooth 1.b chew

$2 . a$

srioke

2.b flame

3.a

drapes

$3.5-\operatorname{rod}$

4. a

bad

4.b _ sickness

5.a _ pencil 5.b _ pen

6.2

Eloor

$6 . b$ - carpet

7. a picture

7.b door

8. $a$ car

8.b _tree 


\section{Word Association Questionnaire \\ Form 1}

Chair

Cherk the word that most people associate with each'stimulus word.

Stimulus Words

\begin{tabular}{|ll|}
\hline 1. & earth \\
2. & dream \\
3. & lift \\
4. & moon \\
5. ocean \\
6. rough \\
7. sheep \\
8. whistle
\end{tabular}

Associate Words

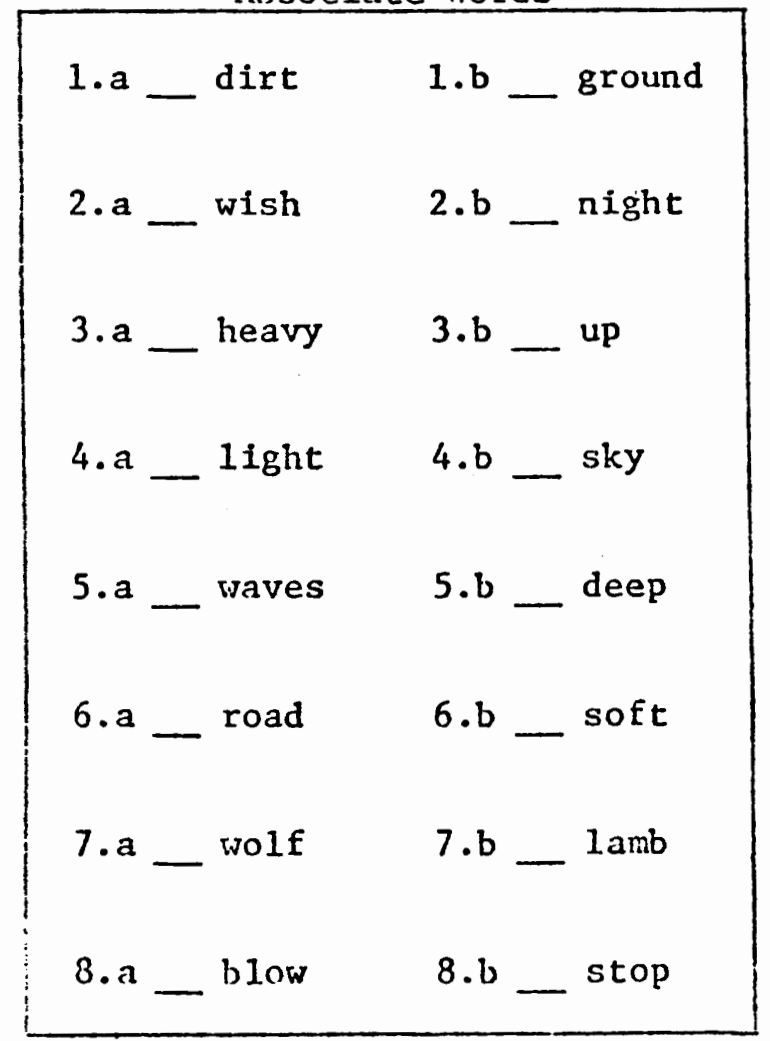

Cutcome:

$\square$ succeed (5 or more correct)

fail ( 4 or less correct) 
Word Association Questionnaire

$$
\text { Form } 2
$$

Chatr

Check the word that most people associate with each stimulus word.

Stimulus Words

1. anger

2. cabbage

3. hand

4. house

5. Loud

6. mountain

7. people

8. stove
Associate Words

\begin{tabular}{|c|c|c|c|}
\hline $1 . a$ & fear & $1 . b$ & hate \\
\hline $2 . a$ & green & $2 . b$ & food \\
\hline $3 . a$ & ring & $3 . b$ & glove \\
\hline $4 . a$ & window & $4 . b$ & roof \\
\hline $5 . a$ & quiet & $5 . b$ & noisy \\
\hline $6 . a$ & valley & $6 . b$ & top \\
\hline $7 . a$ & places & $7 . b$ & animals \\
\hline $8 . a$ & warm & 8.b & fire \\
\hline
\end{tabular}

Outcome: $\square$ succeed (5 or more correct)

$\square$ fail ( 4 or less correct) 


\section{Word Association Questionnaire}

Form 3

\section{Chair}

Check the word that most people associate with each stimulus word.

\section{Stimulus Words}

1. baby

2. fruit

3. head

4. needle

5. priest

6. river

7. salt

8. daughter
Associate Words

$1 . a$ cute

$1 . b$ little

$2 . a$ vegetable $2 . b$ _ eat

3. a eyes

3.b - face

$4 . a$ sew

$4 . b$ pin

$5 . a-\operatorname{god}$ 5.b _ father

$6 . a$ blue

$6 . b$ _ boat

7.a - taste

7.b _ sugar

$8 . a$ child

$8 . b-g i r 1$

Outcome: $\square \quad$ succeed (5 or more correct)

$\square$ fail (4 or less correct) 
Word Association Questionnaire.

Form 4

Chair

Check the word that most people associate with each stimulus word.

Stimulus Words

1. bed

2. dance

3. hunger

4. music

5. mouth

6. scissors

7. table

8. farm
Associate Words

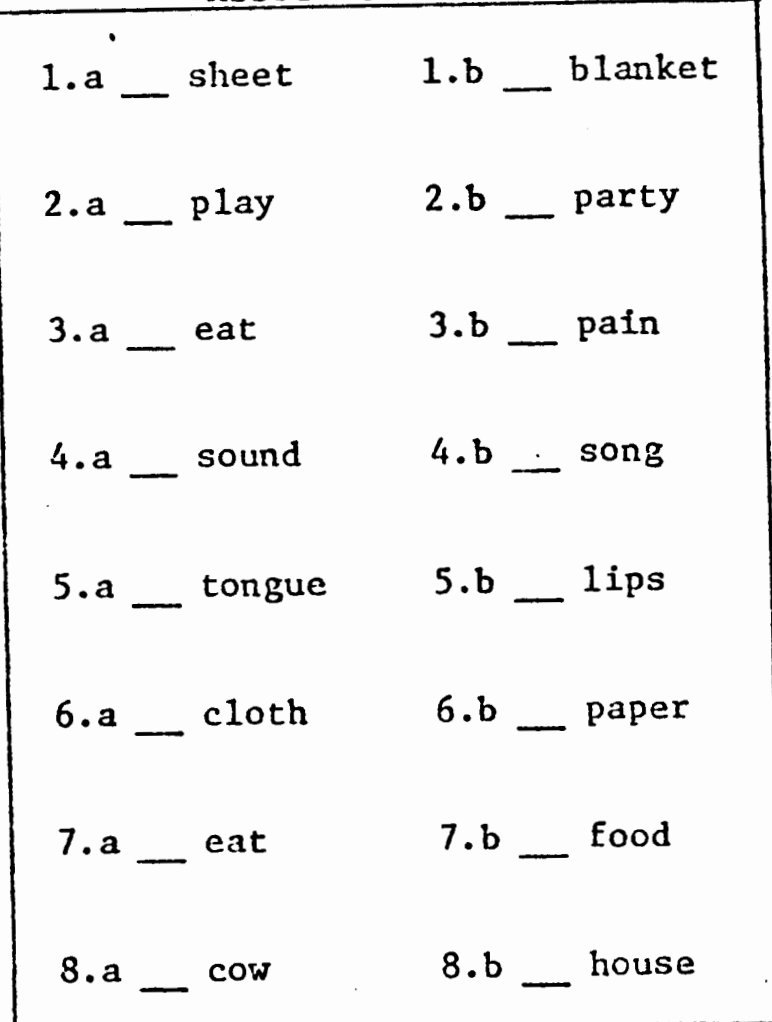

Outcome: $\square$ succeed (5 or more correct)

$\square$ fail (4 or less correct) 


\section{Word Association Questionnalre \\ Form 5}

Chair

Check the word that most people associate with each stimulus word.

Stimulus Words

1. bite

2. fire

3. curtain

4. hospital

5. paper

6. rug

7. screen

8. trunk
Associate Words

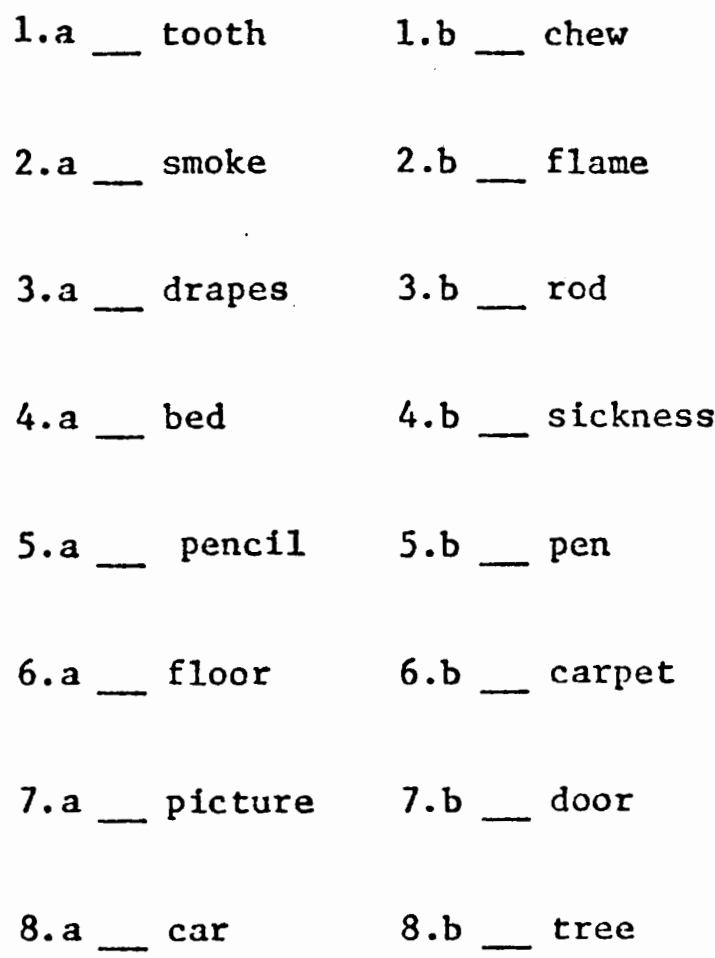

Outcome: $\square$ succeed (5 or more correct)

$\square$ fail (4 or less correct) 


\section{APPENDIX B}

The Word Association Questionnaire

Description: Each item on this questionnaire asks you to predict which of two responses other people give most frequently to a commonly-used word. "Prediction" is a good description of what is involved in this task because many things under your control will determine how you perform. For one thing, you may succeed or fail as a result of your ability to observe and remember what others say, and to be aware of the meanings behind their words. People differ very much on these abilities, and some people succeed almost all the time while others almost always fail. In short, keep in mind that how you do is a matter of skill.

Instructions: You will be given a form with two boxes of words on it. On the left will be the "stimulus words". On the right are the "assoctate words". Two associate words are on the same line as a stimulus word. Although the actual forms contain more items, here is an example of how they are set up:

\begin{tabular}{ll} 
Stimulus Words \\
2. & lettuce \\
\hline
\end{tabular}

$$
\begin{array}{ll}
\text { Associate Words } \\
\hline . a-\text { rabbit } & 1 . b \_ \text {salad } \\
2 . a \perp \text { dull } & 2 . b \_ \text {shiny }
\end{array}
$$

You are to go down the list of stimulus words, one at a time. For each stimulus word, check which of the two associates on the same line you think other people would check most often. The checkmarks in the above example indicate that the respondent believes that most people pick "salad" when asked for an assoriate to "lettuce". When asked for an associate to "bright", the respondcnt also believes that nost others choose "dull" over "shiny". Don't worry about other possjble associates that have not been listed or the most logical choice. Concern yourself with only the two associates given for each stinulus word, and place a check before the associate that others pick most often. 
The Word Association Questionnaire

Description: Each item on this questionnalre asks you to quess which of two responses other people give most of ten to a commonly used word. "Guessing" is a good description of what is involved in this task because many things outside your control will determine how you perform. For one thing, you may succeed or fail as a result of guesses that are right or wrong by chance. You may also succeed or fail as a result of the items which have been selected for you to answer: some sets of ltems are so easy that almost everyone gives correct answers, while other sets of items are so hard that no one is right all the time. In short, keep in mind that how you do on this questionnaire is a matter of luck.

Instructions: You will be given a form with two boxes of words on it. On the left will be the "stimulus words". On the right are the "associate words". Two associate words are on the same line as a stimulus word. Although the actual forms contain more items, here is an example of how they are set up:
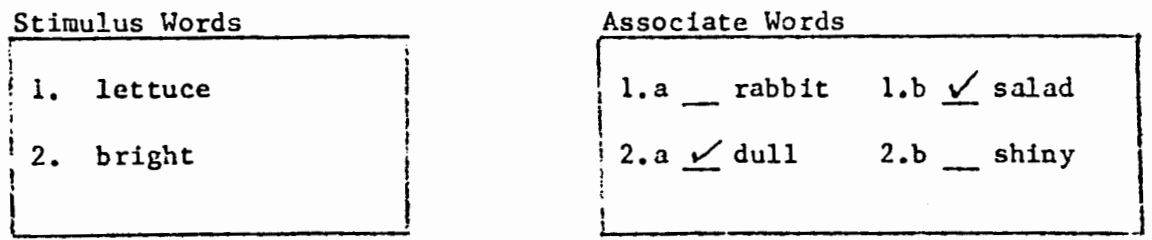

You are to go down the list of stimulus words, one at a time. For each stimulus word, check which of the two associates on the same line you think other people would check most often. The checkmarks in the above example indicate that the respondent belleves that most people pick "salad" when asked for an associate to "lettuce". When asked for an associate to "bright", the respondent also believes that most others choose "dull" over "shiny". Don't worry about other possible associates that have not been listed or the most logical choice. Concern yourself with only the two associates given for each stimulus word, and place a check before the associate that others pick most of ten. 
Description: Each item on this questionnaire asks you to choose whIch of two responses other people give most frequently to a comonly-used word.

Instructions: You will be given a form with two boxes of words on it. On the left will be the "stimulus words". On the right are the "associate words". Two associate words are on the same line as a stimulus word. Although the actual forms contain more items, here is an example of how they are set up:

$\begin{array}{ll}\text { 1. } & \text { lettuce } \\ \text { 2. } & \text { bright }\end{array}$

Associate Words
$\begin{array}{ll}1 . a \_ \text {rabbit } 1 . b \_ \text {salad } \\ 2 . a \simeq \text { dull } & 2 . b \_ \text {shiny }\end{array}$

You are to go down the list of stinulus words, one at a time. For each stimulus word, check which of the two associates on the same line you think other people would check most often. The checkmarks in the above example indicate that the respondent believes that most people pick "salad" when asked for an associate to "lettuce". When asked for an associate to "bright". The respondent also believes that most others choose "dull" over "shiny". Don't worry about other posstble associates that have not been listed or the most logical choice. Concem yourself with only the two associates given for each stimulus word and place a check before the associate that others pick most often. 
APPENDIX C

Future Performance Questionnaire

Age

Sex

Chair

Please use the following list of words to describe how you feel about future performance on the Word Association Questionnalre. Suppose you were given another form of the questionnaire right now. Check each word which describes how you would feel about the prospect of completing the form and recelving feedback on your performance.
1. _ calm
12. _ joyful
2. _ afraid
13. - loving
3. _ desperate
14. - tense
4. _ cheerful
15. — terrified
5. _ fearful
16. _ pleasant
6. - contented
17. _ upset
7. - nervous
18. - secure
8. - frightened
19. - worrying
9. - panicky
20. _ steady
10. _ happy
21. - thoughtful
11. _ shaky 


\section{Performançe Questionnaire}

Check L1st

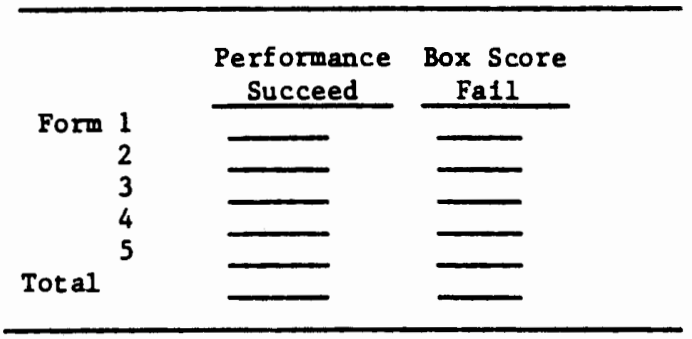
Age
Sex
Chair
1. $\square$ Unhappy
17. $\square$ Buoyant
2. $\square$ Elated
18. $\square$ Dispirited
3. $\square$ Blue
19. $\square$ Weak
4. $\square$ Downcast
20. $\square$ Pleased
5. $\square$ Dejected
21. $\square$ Low
6. $\square$ Fine
22. $\square$ Dratned
7. $\square$ Discouraged
23. $\square$ Burdened
8. $\square$ Gloomy
24. $\square$ Jolly
9. $\square$ Despondent
25. $\square$ Dul1
10. $\square$ Mellow
26. $\square$ Washed Out
11. $\square$ Downhearted
27. $\square$ Unconcerned
12. $\square$ Fallure
28. $\square$ Gray
13. $\square$ Good
29. $\square$ Melancholy
14. $\square$ Glum
30. $\square$ Bright
15. $\square$ Lousy
31. $\square$ wilted
16. $\square$ Peace ful
32. $\square$ Pessimlstic

Directions: Fill in your age and sex above. Below you will find words which describe different kinds of moods and feelings. Check the words which describe how you feel about your performance on the Word Assoclation Questionnaire ( a record of jour performance.18 in the upper right hand comer). Some of the words may sound alike, but we want you to check all the words that describe your feelings. Work rapidly and check all of the words which describe how you feel about your performance. 
Experimental Setting Questionnaire

Ase_ Sex Chair

Please uve the following list of words to describe how you feel about the experimental getting. This might include your feelings toward the experimenter, the questionnalre, and other experimental materials. Also consider any other aspects of the experimental setting you believe are important. Check each word which describes your general feelings rlght now.
1. _ angry
15. _ kindly
2. bitter
16. _ polite
3. _ agreeable
17. $-\operatorname{mad}$
4. - cruel
18. _ oympathetIc
5. amiable
19. - mean
6. _ disagreeable
20. _ tame
7. cooperative
21. __ offended
8. _ friendly
22. _ tender
9. _ discontented
23. outraged
10. disgusted
24. _ stormy
11. _ enraged
25. _ understanding
12. - good-natured
26. _ unsociable
13. _ furlous
27. _ vexed
14. irritated
28. _ positive 
APPENDIX D

Over $50 \%$ success

How much do you take credit for and congratulate yourself for your level of performance?

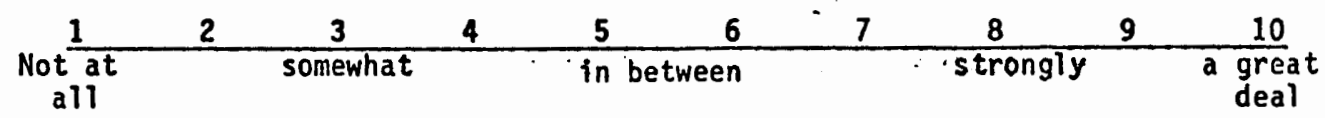

Less than $50 \%$ success

How much did you blame yourself for your level of performance?

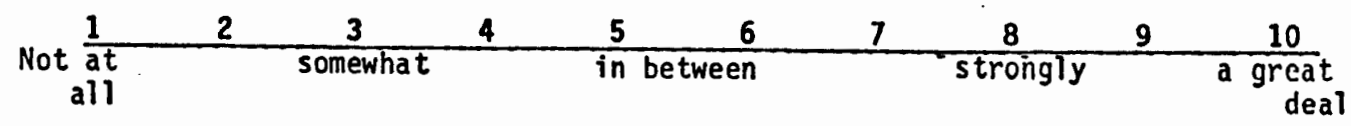

APPENDIX E

To what extent was your performance under your control?

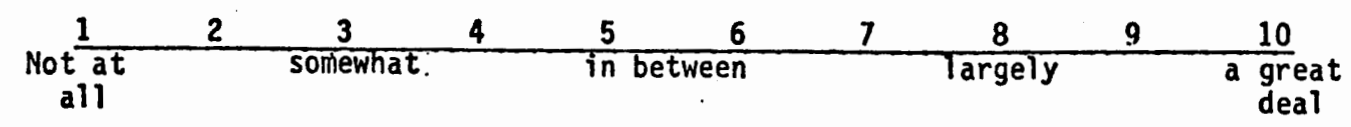


APPENDIX F

SCRIPT

Subject arrives.

THANKS FOR COMING IN (name) PLEASE TAKE A SEAT. FIRST I WOULD LIKE YOU TO READ THIS FORM, (hand subject Informed Consent form) AND IF IT IS AGREEABLE, SIGN AND DATE IT AT THE BOTTOM.

Take back Informed Consent form.

SO THAT EVERYBODY RECEIVES THE SAME INSTRUCTIONS I WILL READ THEM. NOW I WOULD LIKE YOU TO IOOK AT THIS. (Hand appropriate internal, external, or neutral instructions and questionnaire packet.) YOU WILL BE COMPLETING A WORD ASSOCIATION QUESTIONNAIRE. FIRST, LET'S READ THE INSTRUCTIONS.

Read instructions aloud with subject.

DO YOU HAVE ANY QUESTIONS?

If not, ALL RIGHT, LET'S BEGIN WITH THE FIRST TRIAL. TURN TO PAGE 1.

After subject completes first trial, "correct" (by referring to appropriate grading key) and check "succeed" or "fail" on bottom of form while subject watches. Repeat procedure, "grading" after each form is completed. After grading form 5. read appropriate note at bottom of page.

Transfer grades to top of Performance Questionnaire. NOW I WOULD LIKE TO OBTAIN YOUR OPINION ABOUT PARTICIPATION IN THIS EXPERIMENT.

For internals:

IN REPORTING YOUR OPINIONS I WANT YOU TO KEEP IN MIND THE NATURE OF THIS EXPERIMENT. THIS WAS A TEST OF YOUR ABILITY TO OBSERVE AND REMEMBER WHAT OTHERS SAY. IT MEASURED YOUR ABILITY TO PREDICT WHAT RESPONSES MOST PEOPLE GIVE. WHILE SOME PEOPIE TAKING THIS TEST FAIL ALMOST ALL THE ITEMS, OTHERS SUCCEED ON MOST OF THEM. PLEASE KEEP THIS IN MIND AS YOU REPORT YOUR OPINIONS. 
For externals:

IN REPORTING YOUR OPINIONS I WANT YOU TO KEEP IN MIND THE NATURE OF THIS EXPERIMENT. WHAT YOU HAVE JUST COMPLETED WAS A GUESSING TASK. WHETHER YOU SUCCEEDED OR FAIIED DEPENDED MOSTLY ON CHANCE. YOU MAY ALSO HAVE SUCCEEDED OR FAIIED AS A RESULT OF THE ITEMS WE SELECTED. SOME SETS ARE SO EASY THAT PRACTICALLY EVERYONE GIVES CORRECT ANSWERS. OTHER SETS OF ITEMS ARE SO HARD NO ONE GETS THEM ALL RIGHT. PLEASE KEEP THIS IN MIND AS YOU REPORT YOUR OPINIONS.

\section{All:}

Give packet including Performance Questionnaire, Experimental Setting Questionnaire, and Future Performance Questionnaire to subject.

Read instructions aloud with subject.

Retrieve packet.

Success subjects:

YOU SUCCEEDED ON MORE THAN $\frac{1}{2}$ OF THE ITEMS SO I D LIKE YOU TO ANSWER THESE QUESTIONS.

Hand Attribution Questionnaire and Self-evaluation Questionnaire (Credit) to subject.

Failure subjects:

YOU SUCCEEDED ON FEWER THAN $\frac{1}{2}$ OF THE ITEMS SO I'D LIKE YOU TO ANSWER THESE QUESTIONS.

Hand Attribution Questionnaire and Self-evaluation Questionnaire (Blame) to subject.

ALL RIGHT, WE ARE FINISHED.

COULD YOU DETERMINE WHAT EXPERIMENTAL QUESTION WE ARE TRYING TO ANSWER? DEBRIEP.

Possibly reject data.

SINCE OTHER PEOPLE WILL ALSO BECOME SUBJECTS FOR THIS STUDY, IT WOULD HELP US GREATLY IF YOU DID NOT DISCUSS THE EXPERIMENT WITH OTHERS WHO MIGHT PARTICIPATE. WOULD YOU BE WILLING TO DO THIS?

THANK YOU. 


\section{APPENDIX G}

\section{CORRECTION KEY}

The following numbered items on the 5 forms of the Word Association Questionnaire will be marked "correct". Forms will be designated "succeed" or "fail" depending on the letter for that box designated below ( $S$ or $F$ ).

Form

$\begin{array}{llllll}\text { Success } & 1 & 2 & 3 & 4 & 5 \\ \text { feedback } & & & & \end{array}$

Items

$\begin{array}{llll}\text { correct } & 1,2,3,5 & \begin{array}{l}1,3,5, \\ 7,8\end{array} & 6,7,8\end{array} \quad \begin{array}{ll}1,3,6,8 & 2,3,4,6,1,2,3, \\ 7,8 & 4,5,7\end{array}$

Designated $\mathrm{S}$

S $\quad$ F $\quad$ S

S

Failure

feedback

$1,2,5 \quad 3,5,7 \quad 1,2,5,7,2,3,4,8 \quad 3,6$

Designated

F

F

S

F

F 